\title{
SIMILARITY BETWEEN SEED BANK AND HERB LAYER IN A NATURAL DECIDUOUS TEMPERATE LOWLAND FOREST
}

\author{
Maciej WódKIEwicz ${ }^{1}$, AnNA Justyna KwiATKOWsKA-FalińsKA ${ }^{2}$ \\ ${ }^{1}$ Department of Plant Ecology and Environmental Conservation, University of Warsaw \\ Al. Ujazdowskie 4, 00-478 Warszawa, Poland \\ e-mail:wodkie@biol.uw.edu.pl \\ ${ }^{2}$ Geobotanical Station in Białowieża, University of Warsaw \\ Sportowa 19, 17-230 Białowieża, Poland
}

(Received: October 19, 2009. Accepted: February 10, 2010)

\begin{abstract}
Forest seed banks mostly studied in managed forests proved to be small, species poor and not reflecting aboveground species composition. Yet studies conducted in undisturbed communities indicate a different seed bank characteristic. Therefore we aimed at describing soil seed bank in an undisturbed forest in a remnant of European lowland temperate forests, the Białowieża Forest. We compared similarity between the herb layer and seed bank, similarity of seed bank between different patches, and dominance structure of species in the herb layer and in the seed bank of two related oak-hornbeam communities. We report relatively high values of Sorensen species similarity index between herb layer and seed bank of both patches. This suggests higher species similarity of the herb layer and soil seed bank in natural, unmanaged forests represented by both plots than in fragmented communities influenced by man. Although there was a set of core seed bank species present at both plots, yielding high Sorensen species similarity index values, considerable differences between plots in seed bank size and dominance structure of species were found, indicating spatial variability of studied seed bank generated by edaphic conditions. Dominance structure of species in the herb layer was not reflected in the underlying seed bank. This stresses, that natural forest regeneration cannot rely only on the seed bank, although some forest species are capable of forming soil seed banks. While forest seed banks may not reflect vegetation composition of past successional stages, they may inform on history and land use of a specific plot.
\end{abstract}

KEY WORDS: Białowieża primeval forest, oak-hornbeam, seed extraction method, soil seed bank, species dominance structure, species similarity.

\section{INTRODUCTION}

In spite of several decades of intensive research on seed banks, temperate deciduous forest seed banks are still incompletely studied. Majority of seed bank literature is concerned with arable and open communities (Thompson et al. 1997; Jensen 1998; Caballero et al. 2003; Decaëns et al. 2003), managed communities (Van der Reest and Rogarr 1988; Thompson et al. 1994; Bekker et al. 1997; Halpern et al. 1999; Bossuyt and Hermy 2003), or changes in seed bank size and composition in the course of primary (Grandin and Rydin 1998) and secondary (Milberg 1995; Falińska 1999; Hyatt and Casper 2000) succession. Much less work has been done in forests, mainly in secondary communities (Hill and Stevens 1981, Brown and Oosterhuist 1981; Granström 1982; Beatty 1991; Kjellson 1992; Warr et al. 1994; Halpern et al. 1999; Bossuyt et al. 2002;
Olano et al. 2002), which were for centuries exploited intensively and transformed.

Based on studies in forests substantially influenced by man a picture of a small and species poor forest soil seed bank arises. Thompson (1978) links this with low level of disturbance and high level of stress (poor light conditions) in mature forests, factors not promoting the formation of a permanent soil seed bank. Forest soil seed banks are characterized by dominance of 'pioneer' species absent from the forest floor and typical of open, early successional communities (Thompson 1978; Brown and Oosterhuis 1981; Warr et al. 1993; 1994; Halpern et al. 1999; Hyatt 1999; Bossuyt and Hermy 2001; Bossuyt et al. 2002). These findings are in accordance with the widely accepted idea that the strategy of spreading risk in time associated with maintaining a soil seed bank is reserved mainly for small seeded and light demanding species. This leads to high dis- 
similarity between species composition of forest herb layer (composed of stress tolerant species with heavy seeds and no light requirements for germination) and soil seed bank (Brown and Oosterhuis 1981; Kjellsson 1992; Bossuyt et al. 2002). Therefore many authors assume that forest seed banks reflect the history of species composition of a vegetation plot at earlier successional stages (Warr et al. 1993, 1994; Clark et al. 1999; Halpern et al. 1999; Hyatt and Casper 2000; Bossuyt et al. 2002).

According to the literature the discrepancy between the soil seed bank and overlying vegetation is caused by lack of forest species' ability to develop permanent seed banks, and that pioneer rural species, found in forest soil, presumably from past early succession stages, produce long-lived seeds capable of creating permanent soil seed banks (Thompson et al. 1998; Halpern et al. 1999; Hermy et al. 1999; Honnay et al. 2002; Bossuyt et al. 2002). Harper (1977) concluded that forest species produce vegetative propagule banks, but are not capable of forming seed banks. Forests were perceived as stable environments lacking disturbance in comparison with open and managed communities. In such stable systems the formation of soil seed banks seemed not favoured. The reason of the lack of ability of forest species to form soil seed banks was that large seeds of forest species should be preferred food of granivorous rodents (Thompson et al. 1993). Some authors underline that forest soil seed bank composition may be more connected with surrounding present vegetation than with vegetation history of a plot (Kellman 1974; Beatty 1991; Kjellsson 1992). This idea seems to well explain the pattern of forest soil seed bank in a fragmented landscape in which forest communities are intermingled with managed communities dominated by pioneer species.

In contrast to prevailing literature concerned with managed systems only a limited number of studies were aimed at understanding the functioning of a seed bank in natural temperate forests (Kellman 1974; Granström 1987; Hyatt 1999; Leckie et al. 2000; Panufnik-Mędrzycka and Kwiatkowska-Falińska 2001). One reason may be that natural forests are scarce due to anthropogenic pressure, therefore number of sites for investigation is limited. One of their remnants is Białowieża Primeval Forest, a model system for natural European lowland forests. The seed bank of Białowieża forests shows a different characteristic than widely studied seed banks of western European forests, that is high similarity between species composition of seed bank and herb layer and low fraction of seeds of pioneer species (Pirożnikow 1983; Jankowska-Błaszczuk and Grubb 1997; Jankowska-Błaszczuk 1998; Jankowska-Błaszczuk et al. 1998). In Białowieża Forest seed banks there was also a number of old forest species (Hermy et al. 1999; Dzwonko and Loster 2001). Some recent results from Bialowieża Forest show that the strategy of forming soil seed bank can also be favoured by small scale disturbances, which naturally occur in mature forests (Jankowska-Blaszczuk 2006; Jankowska-Blaszczuk and Grubb 2006; Jankowska-Blaszczuk and Daws 2007).

Methodological constrains on the quantity of vegetation plots and soil samples representing each plot to be analysed during one study, and the spatially diverse nature of soil seed bank at different spatial scales (Thompson 1986; Olano et al. 2002) created a need for yet another study of oak-hornbeam soil seed bank. In previous research of Bia- łowieża forest soil seed banks, soil samples of large volume were taken from few sample points of the study plot. Our sampling scheme was based on the assumption that it is better to take many small samples rather than a few large ones (Benoit et al. 1989). Our main questions were: 1 . What is species similarity between the herb layer and seed bank? 2. What is species similarity of seed bank between plots of oak-hornbeam communities differing in stand structure, soil moisture and fertility? 3. Is the dominance structure of species in the herb layer reflected in the seed bank? We aimed at describing the soil seed bank in natural oak-hornbeam forest taking into account the environmental diversity of this community. Deciduous forests are a potential vegetation type in temperate zone, once covering most of Europe, therefore understanding processes ongoing in such natural systems may be helpful in protection and restoration of such disturbed ecosystems.

\section{MATERIALS AND METHODS}

\section{Study area}

The study was conducted on two plots $(2 \times 40 \mathrm{~m}$ each $)$ situated in a mature, undisturbed oak-hornbeam forest. One of them was located in the strict reserve of Białowieża Na-

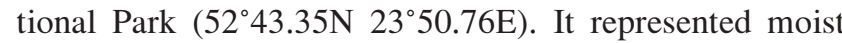
and fertile variant Tilio-Carpinetum stachyetosum (Matuszkiewicz 2001). The herb layer of this community is composed of species requiring rich soil. The other plot was situated a few kilometres S-W in Szafer Landscape Reserve $\left(52^{\circ} 41.79 \mathrm{~N} 23^{\circ} 48.74 \mathrm{E}\right)$. It represented a dryer and less fertile variant Tilio-Carpinetum typicum (Matuszkiewicz 2001). The herb layer of this community is poorer than in the first one, lacking the more demanding species. The tree stand in both communities is multilayered allowing only $10 \%$ of sunlight to reach the forest floor during the vegetation period (Słomka 1967). It is composed of trees of different species (Acer platanoides, Carpinus betulus, Picea abies, Quercus robur, Tilia cordata, Ulmus glabra), and of varying age and size. The herb layer covers $60-90 \%$ of the forest floor and is composed of different species, which form clusters on the forest floor.

\section{Data collection}

Each study plot was divided into 20 squares $2 \times 2 \mathrm{~m}$. Soil samples for seed bank analysis were collected in November 2001. Litter was removed before sampling in order to exclude the presence of seeds from the recent seed rain. This step was performed because this study attempted to census the persistent seed bank. In each square four soil samples were extracted from upper $(0-5 \mathrm{~cm})$ and four from lower $(5-10 \mathrm{~cm})$ soil layer yielding 80 soil samples from each soil layer of a total volume of $15.9 \mathrm{dm}^{3}$ and $0.159 \mathrm{~m}^{2}$ per study plot. Each soil sample was composed of three soil cores with a diameter of $2.9 \mathrm{~cm}$ and height of $5 \mathrm{~cm}$ (Fig. 1). The sample volume was approximately $100 \mathrm{~cm}^{3}$ covering the area of $20 \mathrm{~cm}^{2}$.

Soil samples were dried and sieved through mesh sizes of $1 \mathrm{~mm}, 0.5 \mathrm{~mm}$, and $0.25 \mathrm{~mm}$ yielding four soil fractions. Seeds were extracted under stereoscopic microscope from three largest soil fractions. The finest soil fraction was not examined, as most species produce seeds larger than 0.25 $\mathrm{mm}$. Seeds were determined to species level according to 


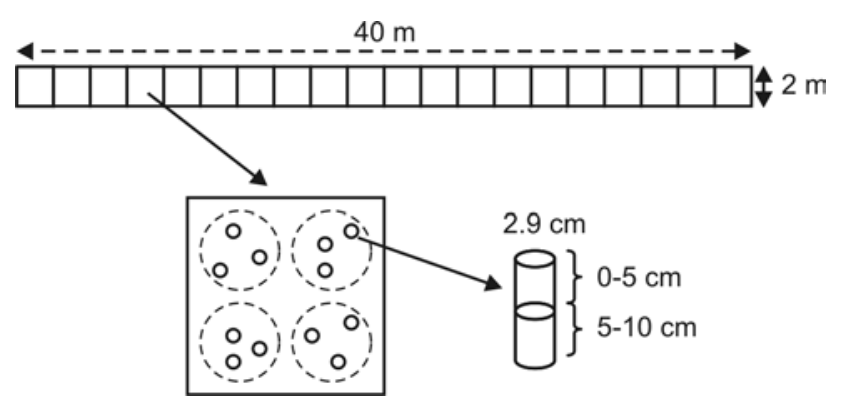

Fig. 1. Field sampling scheme.

a reference collection gathered by the authors. Viability of extracted seeds was determined based on previous literature on seed banks in Białowieża Forest (Pirożnikow 1983; Jankowska-Błaszczuk 1998; Jankowska-Błaszczuk et al. 1998; Panufnik-Mędrzycka and Kwiatkowska-Falińska 2001).

Species composition of the herb layer and number of shoots (vegetative and generative) in each square was determined in May and August in 2002. All ramets of clonal species were counted as separate shoots as this reflects the abundance of each species on the forest floor.

\section{Data analysis}

Number of shoots per square meter was calculated by dividing total number of shoots recorded by total area of study plot. Number of diaspores per square meter was calculated by dividing number of seeds of a species extracted from soil samples from a soil layer by area of samples taken at each study plot. Dominance structure of species in the herb layer was based on frequency of species in squares and on number of shoots per square meter. Dominance structure of species in the seed bank was based on species frequency in soil samples and on number of seeds from each soil layer. Species similarity between soil seed bank and herb layer, between seed bank from both soil layers, and similarity of soil seed bank and herb layer between both studied plots were calculated with Sorensen index (Legendre and Legendre 1998). Species similarity between plots was also calculated for the herb layer and both soil layers with Steinhaus similarity index, which is a quantitative equivalent of Sorensen index (Legendre and Legendre 1998). Pterydiophytes were excluded from analysis. Correlation between species frequency in the herb layer and seed bank at both soil layers, correlation between species frequency and abundance (number of seeds in seed bank and number of shoots in the herb layer) in the herb layer and seed bank at both soil layers was analysed with Spearman rank order correlation coefficient (Sokal and Rohlf 1995). Statistical analysis was conducted with SAS V8 system (SAS Institute Inc. 1999). Nomenclature follows Mirek et al. 2002.

\section{RESULTS}

\section{Overall seed bank characteristics}

The Tilio-Carpinetum typicum (T.-C.t.) seed bank was over three times smaller than Tilio-Carpinetum stachyetosum (T.-C.s.) seed bank (Table 1). On both plots about 2/3 of all seeds were extracted from the upper soil layer. In T.-C.t. there were around 1700 seeds $\mathrm{m}^{-2}$ in the upper soil
TABLE 1. General characteristics of seed bank and herb layer of studied plots.

\begin{tabular}{|c|c|c|}
\hline & T.C.s. & T.-C.t. \\
\hline Herb layer species richness & 45 & 24 \\
\hline \multicolumn{3}{|c|}{$0-5 \mathrm{~cm}$ seed bank } \\
\hline Species richness & 25 & 24 \\
\hline Total number of seeds & 1056 & 275 \\
\hline Total seed density (number $\mathrm{m}^{-2}$ ) & 6642 & 1730 \\
\hline \multicolumn{3}{|c|}{$5-10 \mathrm{~cm}$ seed bank } \\
\hline Species richness & 13 & 18 \\
\hline Total number of seeds & 475 & 144 \\
\hline Total seed density (number $\mathrm{m}^{-2}$ ) & 2987 & 906 \\
\hline \multicolumn{3}{|c|}{$0-10 \mathrm{~cm}$ seed bank } \\
\hline Total number of seeds & 1531 & 419 \\
\hline Total seed density (number $\mathrm{m}^{-2}$ ) & 9629 & 2635 \\
\hline
\end{tabular}

layer and around 900 seeds $\mathrm{m}^{-2}$ in the lower soil layer, and in T.-C.s. there were around 6600 seeds $\mathrm{m}^{-2}$ in the upper and around 3000 seeds $\mathrm{m}^{-2}$ in the lower soil layer (Table 1).

There were 24 species identified in T.-C.t. seed bank in the upper soil layer and 18 species in the lower soil layer (Table 1). The herb layer of this plot was composed of 23 seed plants (Fig. 2) and one pterydiophyte. Species similarity coefficient between the herb layer and upper soil layer seed bank was $47 \%$, and $39 \%$ between the herb layer and lower soil layer seed bank. Species similarity between seed bank of both soil layers was $81 \%$.

In the plot situated in T.-C.s. there were 25 species in upper soil layer seed bank and 13 species in the lower soil layer (Table 1). The herb layer of this plot was composed of 41 species of seed plants (Fig. 3) and four pterydiophytes. Species similarity index between the herb layer and upper soil layer seed bank was $48 \%$, and $37 \%$ between the herb layer and lower soil layer seed bank. Similarity between seed bank of both soil layers was $68 \%$.

\section{Similarity between plots}

Sorensen species similarity between the herb layer of both plots was $50 \%$. Species similarity between seed banks of studied plots was much higher (69\% for upper soil layer and $58 \%$ for lower soil layer). Large differences between both plots were revealed in Steinhaus species similarity index. The value of this quantitative similarity index was $19 \%$ for the herb layer, $14 \%$ for the seed bank of upper soil layer, and only $8 \%$ for the seed bank of lower soil layer.

\section{Comparison of dominance structure between the herb layer and seed bank}

Two out of four species with high frequency in the herb layer in T.-C.t. were present in the seed bank (Fig. 2). There were five sub dominating species in the herb layer of this plot. Two of them were found in the seed bank. Two out of three species with moderate frequency in the herb layer (35$-50 \%$ ) were rarely found in soil samples. Species with highest frequency in the soil seed bank (Moehringia trinervia and Veronica officinalis) were rare or absent from the herb layer of the studied plot. No correlation between frequency of species in the herb layer and in upper soil layer seed bank was found (Table 2). We found a negative correlation between frequency of species in the herb layer and in the lower soil layer seed bank and positive correlation between frequency of species in both soil layers (Table 2). 


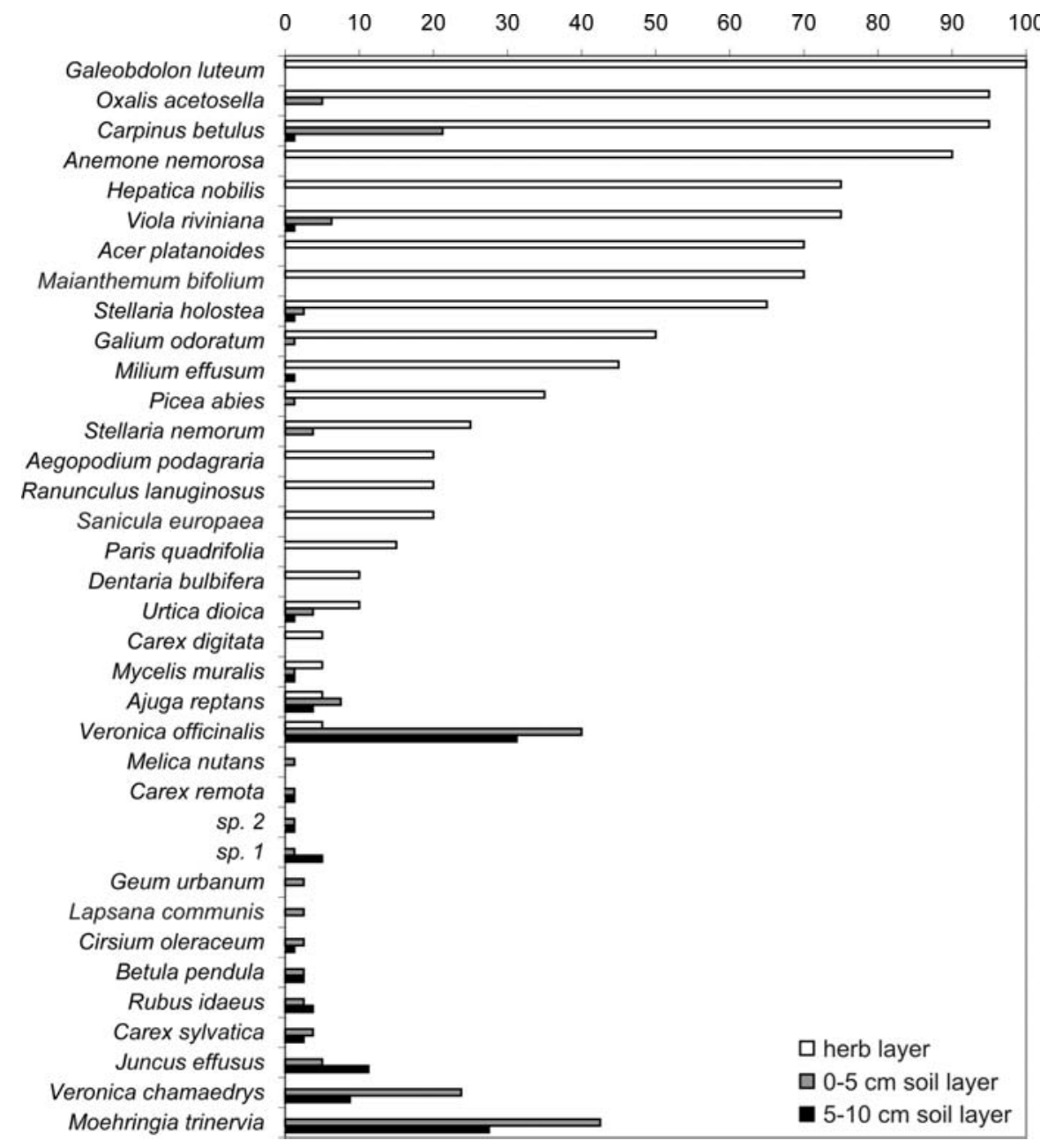

Fig. 2. Frequency of species in the herb layer and seed bank of T.-C.t.

TABLE 2. Spearman correlation coefficient of frequency of species in the herb layer and seed bank of both studied plots. Statistical significance: ns - not significant; $*-\mathrm{p}<0.05 ; * *-\mathrm{p}<0.0001$

\begin{tabular}{lcc}
\hline Correlation between: & T.-C.t. $(\mathrm{n}=36)$ & T.-C.s. $(\mathrm{n}=50)$ \\
\hline Herb layer and $0-5 \mathrm{~cm}$ seed bank & $\mathrm{ns}$ & $\mathrm{ns}$ \\
Herb layer and $5-10 \mathrm{~cm}$ seed bank & $-0.515 *$ & $\mathrm{~ns}$ \\
$0-5 \mathrm{~cm}$ and $5-10 \mathrm{~cm}$ seed bank & $0.680 * *$ & $0.748 * *$ \\
\hline
\end{tabular}

Galeobdolon luteum, Oxalis acetosella and seedlings of Carpinus betulus were most numerous in T.-C.t. herb layer (Fig. 4). Maianthemum bifolium had a much lower density in the herb layer. Shoots of all remaining species were present in the herb layer in small numbers (not exceeding 5 shoots $\mathrm{m}^{-2}$ per species). Dominance structure based on number of seeds in the seed bank differed from dominance structure based on shoot number in the herb layer (Fig. 4). Species with high frequency in the herb layer had also high shoot density and species with high frequency in soil seed bank had numerous seeds deposited in both soil layers (Table 3).

In the herb layer of T.-C.s. 12 out of 41 plant species had high frequency (75\% and higher). Eight of them were present in the soil seed bank (Fig. 3). Only one of eight species moderately frequent $(30-55 \%)$ in the herb layer was present in the soil seed bank. Seeds of four out of 13 species with frequency of $15-25 \%$ in the herb layer were present in the seed bank. Six species found in the soil seed bank were absent from the herb layer of this plot. Carex re- mota and Juncus effusus were dominating the soil seed bank of both soil layers. Carpinus betulus, Chrysosplenium alternifolium, Oxalis acetosella and Urtica dioica were moderately frequent in upper soil layer and rare in the lower soil layer seed bank. No correlation between frequency of species in the herb layer and in the soil seed bank was found (Table 2). Frequency of species in the seed bank of both soil layers was positively correlated (Table 2).

In the herb layer of T.-C.s. the highest number of shoots (exceeding 100 shoots $\mathrm{m}^{-2}$ ) was recorded for Oxalis acetosella and Anemone nemorosa (Fig. 5). Four species had a concentration between 10 and 100 shoots $\mathrm{m}^{-2}$. Shoots of all remaining species were present in the herb layer in small numbers (not exceeding 10 shoots $\mathrm{m}^{-2}$ per species). In T.-C.s. dominance structure in the seed bank based on seed number did not parallel the dominance structure in the herb layer based on shoot number (Fig. 5). We found a high positive correlation between species frequency in the herb layer and number of shoots as well as between frequency of species and seed number in the soil seed bank (Table 3).

\section{DISCUSSION}

\section{General forest seed bank pattern}

Seed bank species richness recorded in both plots was lower than reported in earlier studies of oak-hornbeam forest in Białowieża conducted with seedling emergence method 


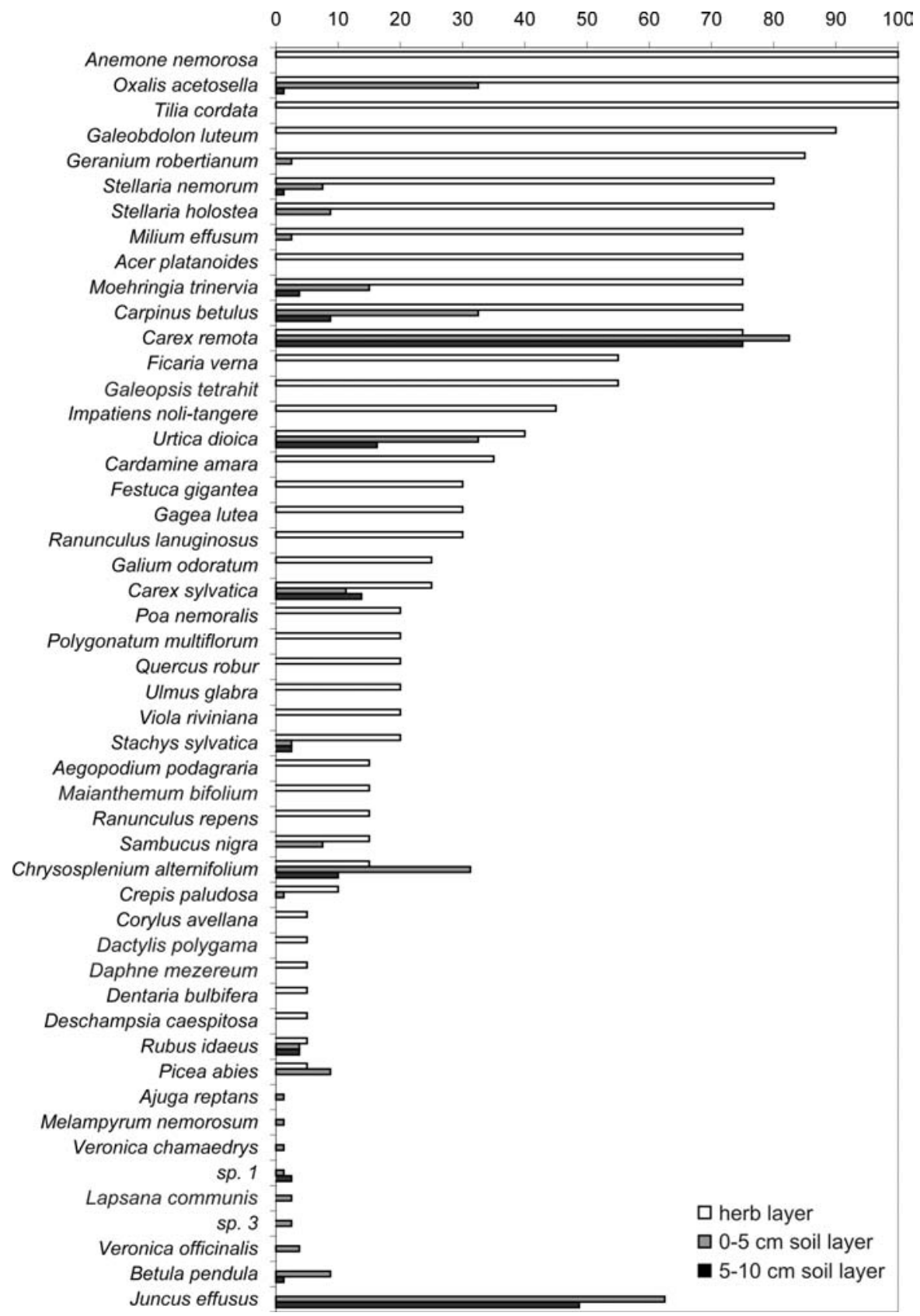

Fig. 3. Frequency of species in the herb layer and seed bank of T.-C.s.

TABLE 3. Spearman correlation coefficient between frequency of species and number of individuals in the herb layer and seed bank of both studied plots, $\mathrm{p}<0.0001$.

\begin{tabular}{lcc}
\hline & T.-C.t. $(\mathrm{n}=36)$ & T.-C.s. $(\mathrm{n}=50)$ \\
\hline herb layer & 0.983 & 0.889 \\
0-5 cm seed bank & 0.994 & 0.996 \\
5-10 cm seed bank & 0.996 & 0.999 \\
\hline
\end{tabular}

(Table 4). It is however within the range of seed bank species richness of different temperate forest communities (Table 4). Although comparison of results concerning seed bank size obtained by different authors is difficult due to methodological differences (Brown 1992), seed bank size recorded by us seems to be of the same magnitude as in other oak-hornbeam seed bank studies conducted with seedling germination method (Jankowska-Błaszczuk and Grubb 1997; Jankowska-Błaszczuk 1998; Jankowska-Błaszczuk et al. 1998), and seed extraction method (Pirożni- kow 1983; Table 4). Our results of seed bank size are also comparable with the estimate of seed bank size in other forest communities (Table 4).

Our study, together with previous research (Pirożnikow 1983; Jankowska-Błaszczuk and Grubb 1997; JankowskaBłaszczuk et al. 1998; Jankowska-Błaszczuk 1998), indicate that seed bank in natural oak-hornbeam communities are spatially diverse concerning species richness and seed bank size. Differences in edaphic conditions between forest stands resembling closely related plant communities may be the main cause of this variation.

\section{Species similarity between the herb layer and seed bank}

The studied plots were not deforested and are an integral part of a large forest complex existing in this location for several thousand years (Ralska-Jasiewiczowa and Latałowa 1996). We recorded a lower species similarity between the herb layer and soil seed bank of studied forest type than reported in previous studies of Białowieża oak-hornbeam fo- 


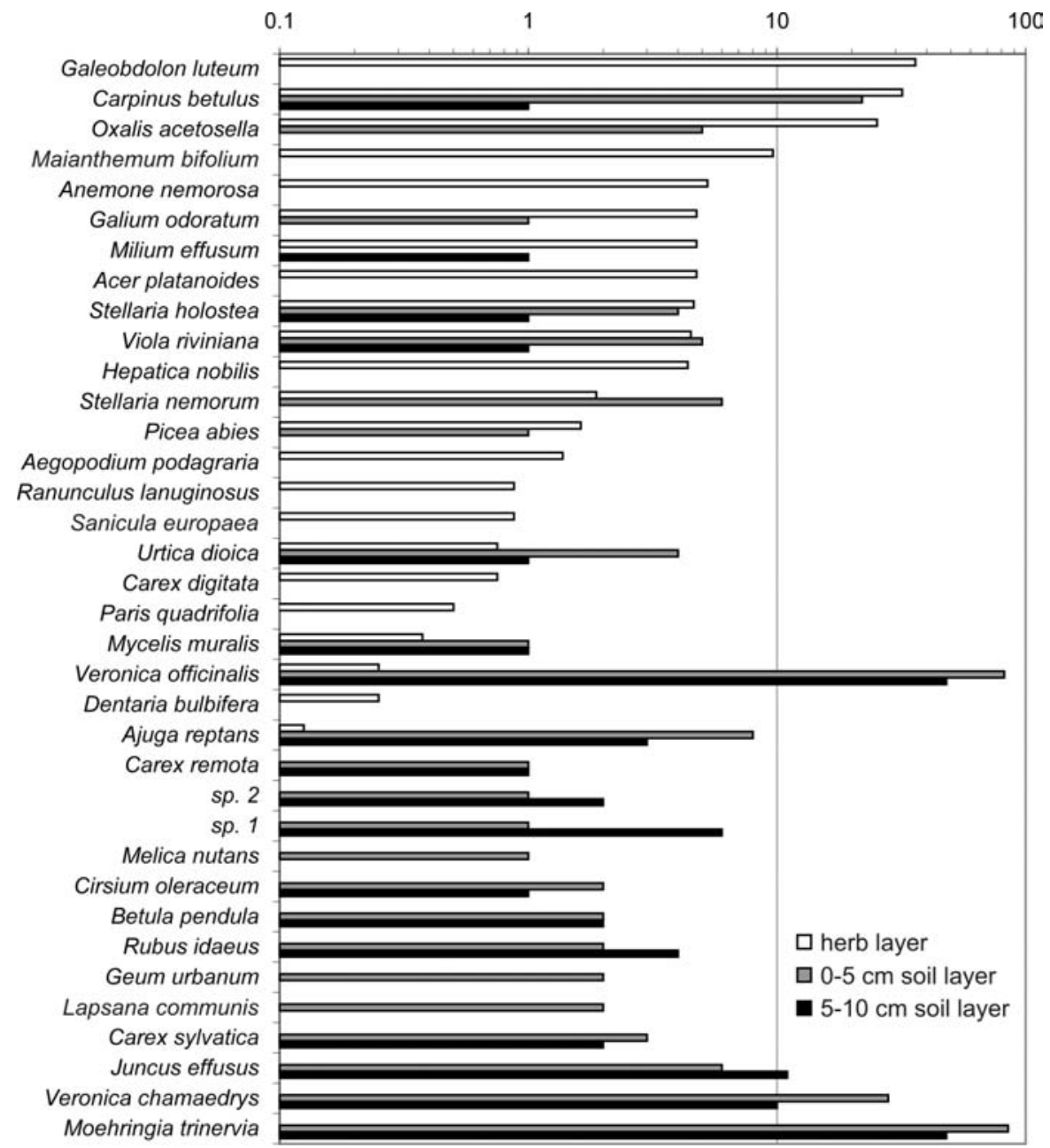

Fig. 4. Number of shoots $\mathrm{m}^{-2}$ in the herb layer and number of seeds in soil of T.-C.t.

TABLE 4. Species richness and seed bank size recorded in different forest communities.

\begin{tabular}{lccc}
\hline Community & No. of species & Seeds $\mathrm{m}^{-2}$ & Reference \\
\hline & & Our results \\
\hline Tilio-Carpinetum stachyetosum & 25 & 9629 \\
Tilio-Carpinetum typicum & 24 & 2635 \\
\hline
\end{tabular}

Results from other studies of Białowieża Forest oak-hornbeam seed bank

\begin{tabular}{lccl}
\hline Tilio-Carpinetum & 33 & $3988-8115$ & Pirożnikow 1983 \\
Tilio-Carpinetum & 46 & 3437 & Jankowska-Błaszczuk and Grubb 1997 \\
Tilio-Carpinetum typicum & 45 & 2412 & Jankowska-Błaszczuk et al. 1998 \\
Tilio-Carpinetum & $40-42$ & $3167-3827$ & Jankowska-Błaszczuk 1998
\end{tabular}

Old growth temperate forests

\begin{tabular}{lccl}
\hline Tilio-Carpinetum corydaletosum & 55 & $888-1394$ & Jankowska-Błaszczuk 2006 \\
Milio-Fagetum (ancient forest) & 28 & 9400 & Bossuyt et al. 2002 \\
Potentillo albae-Quercetum & 51 & 1108 & Jankowska-Błaszczuk et al. 1998 \\
Potentillo albae-Quercetum & 76 & 1547 & Panufnik-Mędrzycka and Kwiatkowska-Falińska 2001 \\
Various deciduous forests & $8-27$ & $2230-15630$ & Kjellsson 1992 \\
Various deciduous forest & $5-17$ & $482-16954$ & Leckie et al. 2000 \\
\hline
\end{tabular}

Secondary temperate forests and plantations

$\begin{array}{lccl}\text { Milio-Fagetum (recent forest) } & 19-24 & 8667 & \text { Bossuyt et al. 2002 } \\ \text { secondary deciduous forest } & 28 & 7057 & \text { Olano et al. 2002 } \\ \text { Various managed forests } & 6-39 & 3240-112480 & \text { Warr et al. 1994 } \\ \text { Managed coniferous forests } & 5-10 & 239-763 & \text { Granström 1982 } \\ \text { Various forest plantations } & 4-14 & 65-1981 & \text { Hill and Stevens 1981 } \\ \text { Coniferous forest plantations } & 23-27 & 610-7009 & \text { Halpern et al. 1999 }\end{array}$




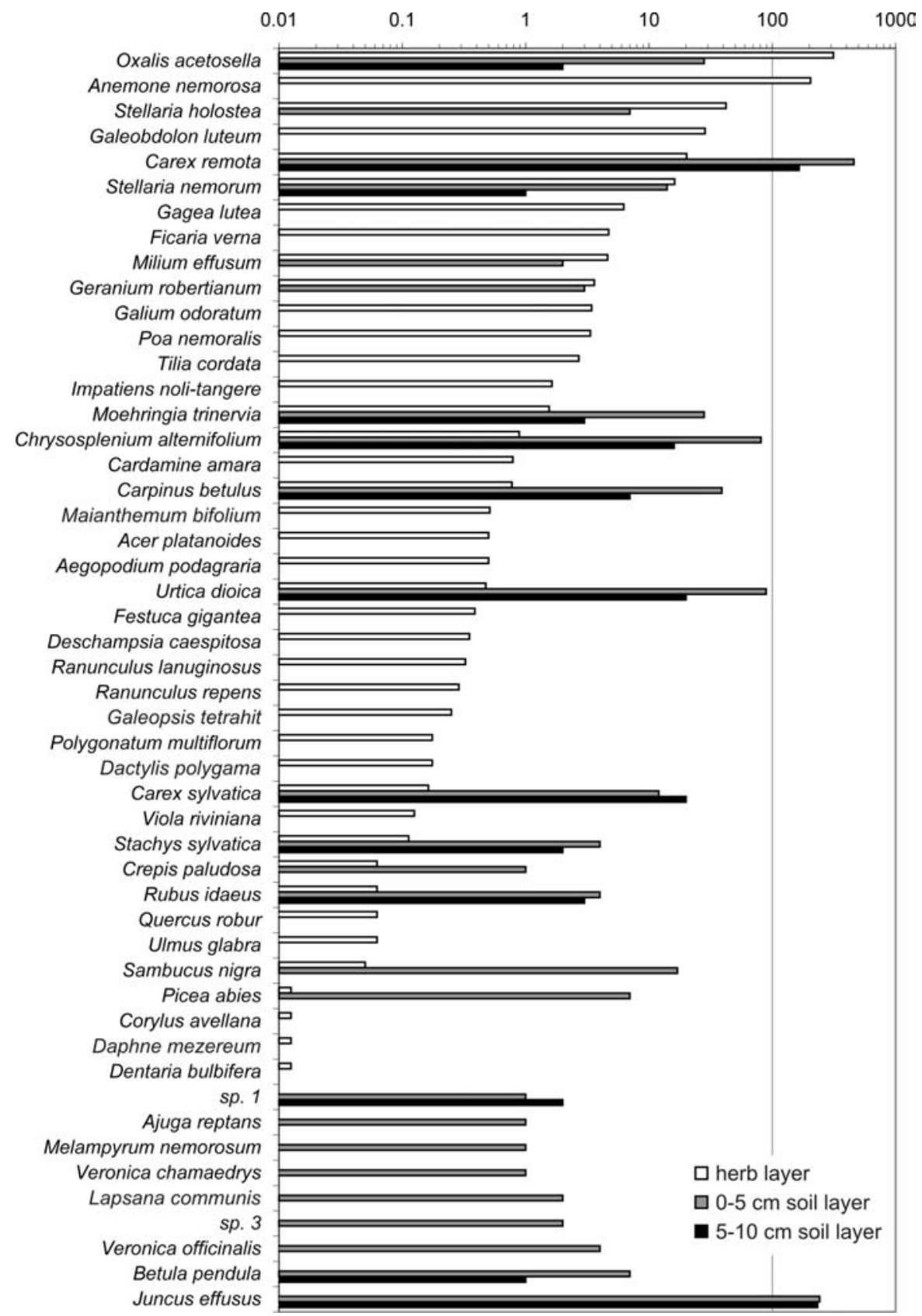

Fig. 5. Number of shoots $\mathrm{m}^{-2}$ in the herb layer and number of seeds in soil of T.-C.s.

rests (around 70\%; Jankowska-Błaszczuk 1998; Jankowska-Błaszczuk et al. 1998). It is however higher than average similarity of forest herb layer and seed bank reported by Hopfensperger (2007). Results from natural, undisturbed forests of North America also indicate a relatively high similarity index between species composition of the seed bank and forest floor (Leckie et al. 2000). Granström (1982) and Kjellsson (1992) studying forest communities on former forest stands reported much higher similarity index than Bossuyt et al. (2002), who studied forests growing on former arable lands. All these findings confirm the idea pointed out by Bossuyt and Hermy (2001) that land use type, stand history and species composition can all have impact on species similarity between seed bank and standing vegetation.

Vertical seed bank pattern described in our study and in previous research of seed banks in Białowieża Forest reflects a steady influx of herb layer species' seeds into the soil. The fragmented forests of west Europe are in a diffe- rent situation concerning their genesis and place in the surrounding landscape (Grashof-Bokdam and Geertsema 1998), hence having a different seed bank pattern. Therefore our results do not fully support the idea, that species composition of forest seed bank reflects earlier succession stages rather than present vegetation (Brown and Oosterhuis 1981; Warr et al. 1993, 1994; Bossuyt et al. 2002), but it is not disproving that the forest seed bank maintains information on previous vegetation history (Plue et al. 2009).

\section{Similarity between different oak-hornbeam patches}

Our results indicate high species similarity of seed bank between different patches of oak-hornbeam. There is a group of core seed bank species in this type of forest community yielding high Sorensen similarity index. On the other hand this similarity was not reflected in dominance structure of species. Species were present with different seed number in the seed bank of each community yielding low values of Steinhaus similarity index. This may have an im- 
pact on potential role of each species in the seed bank of studied communities. The variability of species composition of oak-hornbeam soil seed bank can be associated with differences in species composition of the herb layer (Hyatt and Casper 2000; Leckie et al. 2000; Olano et al. 2002). These differences may be induced by dissimilarity in edaphic conditions between the studied communities. Limitations in seed dispersal (Kellman 1974; Hughes and Fehey 1991; Chambers and MacMahon 1994; Brunet and von Oheimb 1998; Bossuyt et al. 1999; Ehrlen and Eriksson 2000; Dzwonko 2001a, b; Mayer et al. 2004), and spatially variable granivorous animal activity (Abramsky 1983; Vander Wall 1993, 1998; Hulme and Hunt 1999; Alcantara et al. 2000; Rey et al. 2002; Honek et al. 2003) can also have an impact on the diversity of studied seed bank.

\section{Species dominance structure}

Our data on species dominance structure in the herb layer and seed bank, based both on frequency of species and abundance (number of shoots in the herb layer and number of seeds in the seed bank) suggest division of oak-hornbeam species into two groups. One group is composed of species with marginal importance in the herb layer and strongly contributing to the seed bank. The other constitutes of species common in the herb layer and underrepresented in the seed bank.

Species frequent in the soil seed bank of T.-C.t. were absent or rare in the herb layer of this community. Their occurrence is connected with local micro-disturbance of superficial soil layer and litter. Similar results were reported by a number of authors (Thompson and Grime 1979; Kjellsson 1992; Jankowska-Błaszczuk 1998; Bossuyt and Hermy 2001; Bossuyt et al. 2002). Marginal contribution of Juncus effusus seeds (species frequently found in soil seed bank of many forest communities) may be attributed to lack of recent disturbance in forest canopy (presence of old tree specimens) and lack of $J$. effusus individuals in vicinity of the studied plot (Beatty 1991; Kjellsson 1992; Mayer et al. 2004). Soil seed bank of this forest does not reflect quantitative relations between species present in the herb layer. This has an impact on regeneration capability of the herb layer. It can not mainly rely on seed store in the soil, but in a large part is supported by vegetative dispersion (Mayer et al. 2004).

Higher similarity of dominance structure of species in the seed bank and in the herb layer of T.-C.s. results from higher frequency of species producing long-lived diaspores in the herb layer of this community. One of those species is Carex remota, which has its ecological optimum concerning moisture and light requirements in this forest type, and also produces numerous seeds, which are readily incorporated in the soil seed bank. The source of seeds of the other dominant seed bank species, Juncus effusus, may be forest patches in the vicinity, which suffered a windfall, and have a disturbed canopy layer structure. Kjellsson (1992) reported similar results concerning the ability of seed penetration from surrounding vegetation into the forest seed bank.

The dominance structure of the herb layer was not reflected in the seed bank of both studied plots. A number of forest species were noted to exhibit different survival strategies at the same time (Bierzychudek 1982; Hughes and Fahey 1991). As well as acquiring of forest floor space by means of vegetative growth (rhizomes, runners), forest species reproduce generatively taking new sites available in space by seed dispersal and in time through creating soil seed bank (Brunet and von Oheimb 1998; Bossuyt and Hermy 2001; Mayer et al. 2004). This soil seed bank characteristics contrasts with the idea that the strategy of spreading the risk related with germination in time associated with creating soil seed banks is not present in forest species due to a stable forest environment (Harper 1977; Thompson 1987). On the other hand, as discussed by JankowskaBłaszczuk and Grubb (2006) forest species forming soil seed banks may benefit from even small disturbances in herb canopy, litter layer, superficial soil layer, and even single branch fall from forest canopy indicated by changes in light quality (Jankowska-Błaszczuk and Daws 2007).

\section{CONCLUSION}

The size and species richness of forest soil seed banks is highly variable, and although forest seed banks can not be considered to be the largest ones, they can neither be generalized to be small and species poor. Some forest species posses the ability to form soil seed banks.

Our results show a high species similarity of the herb layer and soil seed bank in natural, unmanaged forests. It is higher than mean similarity index calculated for European forests mainly represented by fragmented communities influenced by man. We may suggest that species similarity between the herb layer and soil seed bank in forest communities may be used as a measure of their level of anthropogenic transformation.

High species similarity of seed bank between different patches of oak-hornbeam is the outcome of presence of a group of core species composing the seed bank of different variants of this community. This similarity is not however reflected in dominance structure of species in the seed bank, and may be largely influenced by different edaphic conditions.

The dominance structure of species in the herb layer is not reflected in the underlying seed bank. This stresses, that natural forest regeneration cannot rely solely on the seed bank, although the forest seed bank may posses some value in the regeneration processes of such communities. The practical outcome of our findings is that special care must be taken in forestry practices not to destroy the herb layer if the objective of such practices is the naturalisation of a specific forest community.

\section{ACKNOWLEDGEMENTS}

Authors would like to thank Białowieża National Park for the possibility to conduct this study, Marta Badurek for help in field work, and an anonymous referee for helpful comments on the manuscript.

\section{LITERATURE CITED}

ABRAMSKY Z. 1983. Experiments on seed predation by rodents and ants in Israeli desert. Oecologia 57: 328-332.

ALCANTARA J.M., REY P.J., SANCHEZ-LAFUENTE A.M., VALERA F. 2000. Early effects of rodent post-dispersal seed 
predation on the outcome of the plant-seed disperser interaction. Oikos 88: 362-370.

BEATTY S.W. 1991. Colonisation dynamics in a mosaic landscape: the buried seed pool. J. Biogeogr. 18: 553-563.

BEKKER R.M., VERWEIJ G.L., SMITH R.E.N., REINE R., BAKKER J.P., SCHNEIDER S. 1997. Soil seed banks in European grasslands: does land use affect regeneration perspectives? J. Appl. Ecol. 34: 1293-1310.

BENOIT D.L., KENKEL N.C., CAVERS P.B. 1989. Factors influencing the precision of soil seed bank estimates. Can. J. Bot. 67: 2833-2840.

BIERZYCHUDEK P. 1982. Life histories and demography of shade-tolerant temperate forest herbs: a review. New Phytol. 90: 757-776.

BOSSUYT B., HERMY M. 2001. Influence of land use history on seed banks in European temperate forest ecosystems: a review. Ecography 24: 225-238.

BOSSUYT B., HERMY M. 2003. The potential of soil seedbanks in the ecological restoration of grassland and heathland communities. Belg. J. Bot. 136: 23-34.

BOSSUYT B., HERMY M., DECKERS J. 1999. Migration of herbaceous plant species across ancient-recent forest ecotones in central Belgium. J. Ecol. 87: 628-638.

BOSSUYT B., HEYN M., HERMY M. 2002. Seed bank and vegetation composition of forest stands of varying age in central Belgium: consequences for regeneration of ancient forest vegetation. Plant Ecol. 162: 33-48.

BROWN A.H.F., OOSTERHUIS L. 1981. The role of buried seeds in coppicewoods. Biol. Conserv. 21: 19-38.

BROWN D. 1992. Estimating the composition of a forest seed bank: a comparison of the seed extraction and seedling emergence methods. Can. J. Bot. 70: 1603-1612.

BRUNET J., VON OHEIMB G. 1998. Migration of vascular plants to secondary woodland in southern Sweden. J. Ecol. 86: 429-438.

CABALLERO I., OLANO J.M., LOIDI J., ESCUDERO A. 2003. Seed bank structure along a semi-arid gypsum gradient in Central Spain. J. Arid Environ. 55: 287-299.

CHAMBERS J.C., MACMAHON J.A. 1994. A day in the life of a seed - movements and fates of seeds and their implications for natural and managed systems. Ann. Rev. Ecol. Syst. 25: 263-292.

CLARK J.S., BECKAGE B., CAMILL P., CLEVELAND B., HILLERISLAMBERS J., LICHTER J., MCLACHLAN J., MOHAN J., WYCKOFF P. 1999. Interpreting recruitment limitation in forests. Am. J. Bot. 86: 1-16.

DECAËNS T., MARIANI L., BETANCOURT N., JIMÉNEZ J.J. 2003. Seed dispersion by surface casting activities of earthworms in Colombian grasslands. Acta Oecol. 24: 175-185.

DZWONKO Z., LOSTER S. 2001. Wskaźnikowe gatunki roślin starych lasów i ich znaczenie dla ochrony przyrody i kartografii roślinności. Geogr. Stud. 178: 119-132. (in Polish and English summary)

DZWONKO Z. 2001a. Migration of vascular plant species to a recent wood adjoining ancient woodland. Acta Soc. Bot. Pol. 70: 71-77.

DZWONKO Z. 2001b. Effect of proximity to ancient deciduous woodland on restoration of the field layer vegetation in a pine plantation. Ecography 24: 198-204.

EHRLEN J., ERIKSSON O. 2000. Dispersal limitation and patch occupancy in forest herbs. Ecology 81: 1667-1674.

FALIŃSKA K. 1999. Seed bank dynamics i abandoned meadows during a 20-year period in the Białowieża National Park. J. Ecol. 87: 461-475.

GRANDIN U., RYDIN H. 1998. Attributes of the seed bank after a century of primary succession on islands in Lake Hjälmaren, Sweden. J. Ecol. 86: 293-303.

GRANSTRÖM A. 1982. Seed banks in five boreal forest stands originating between 1810 and 1963. Can. J. Bot. 60: 1815$-1821$.
GRANSTRÖM A. 1987. Seed viability of fourteen species during four years of storage in a forest soil. J. Ecol. 75: 321-331.

GRASHOF-BOKDAM C.J., GEERSTEMA W. 1998. The effect of isolation and history on colonization patterns of plant species in secondary woodland. J. Biogeogr. 25: 837-846.

HALPERN B.C., EVANS S.A., NIELSON S. 1999. Soil seed banks in young closed-canopy forests of Olympic Peninsula, Washington: potential contributions to understory reinitiation. Can. J. Bot. 77: 922-935.

HARPER J.L. 1977. Population biology of plants. Academic Press, London, 892 pp.

HERMY M., HONNAY O., FIRBANK L., GRASHOF-BOKDAM C., LAWESSON J.E. 1999. An ecological comparison between ancient and other forest plant species of Europe, and the implications for conservation. Biol. Conserv. 91: 9-22.

HILL M.O., STEVENS P.A. 1981. The density of viable seed in soils of forest plantations in upland Britain. J. Ecol. 69: 693-709.

HONEK A., MARTINKOVA Z., JAROSIK V. 2003. Ground beetles (Carabidae) as seed predators. Eur. J. Entomol. 100: 531-544 .

HONNAY O., BOSSUYT B., VERHEYEN K., BUTAYE J., JACQUEMYN H., HERMY M. 2002. Ecological perspectives for the restoration of plant communities in European temperate forests. Biodiv. Conserv. 11: 213-242.

HOPFENSPERGER K.N. 2007. A review of similarity between seed bank and standing vegetation across ecosystems. Oikos 116: 1438-1448.

HUGHES J.W., FAHEY T.J. 1991. Colonization dynamics of herbs and shrubs in a disturbed northern hardwood forest. J. Ecol. 79: 605-616.

HULME P.E., HUNT M.K. 1999. Rodent post-dispersal seed predation in deciduous woodland: predator response to absolute and relative abundance of prey. J. Anim. Ecol. 68: 417-428.

HYATT L.A. 1999. Differences between Seed Bank Composition and Field Recruitment in a Temperate Zone Deciduous Forest. Am. Midl. Nat. 142: 31-38.

HYATT L.A., CASPER B.B. 2000. Seed bank formation during early secondary succession in a temperate deciduous forest. J. Ecol. 88: 516-527.

JANKOWSKA-BLASZCZUK M. 1998. Variability of the soil seed banks in the natural deciduous forest in the Białowieża National Park. Acta Soc. Bot. Pol. 67: 313-324.

JANKOWSKA-BŁASZCZUK M. 2006. Seasonal diversity, light requirements and seed mass of species in the persistent soil seed bank of a shaded deciduous forest. Pol. Bot. Stud. 22: 261-271.

JANKOWSKA-BŁASZCZUK M., DAWS M.I. 2007. Impact of red: far red ratios on germination of temperate forest herbs in relation to shade tolerance, seed mass and persistence in the soil. Funct. Ecol. 21: 1055-1062.

JANKOWSKA-BŁASZCZUK M., GRUBB P.J. 1997. Soil seed banks in primary and secondary deciduous forest in Białowieża, Poland. Seed Sci. Res. 7: 281-292.

JANKOWSKA-BŁASZCZUK M., GRUBB P.J. 2006. Changing perspectives on the role of the soil seed bank in northern temperate deciduous forests and in tropical lowland rain forests: parallels and contrasts. Perspect. Plant Ecol. 8: 3-21.

JANKOWSKA-BŁASZCZUK M., KWIATKOWSKA A.J., PANUFNIK D., TANNER E. 1998. The size and diversity of the soil seed banks and the light requirements of the species in sunny and shady natural communities of the Białowieża Primeval Forest. Plant Ecol. 136: 105-118.

JENSEN K. 1998. Species composition of soil seed bank and seed rain of abandoned wet meadows and their relation to aboveground vegetation. Flora 193: 345-359.

KELLMAN M. 1974. Preliminary seed budgets for two plant communities in costal British Columbia. J. Biogeogr. 1: 123-133.

KJELLSON G. 1992. Seed banks in Danish deciduous forests: species composition, seed influx and distribution pattern in soil. Ecography 15: 86-100. 
LECKIE S., VELLEND M., BELL G., WATERWAY M.J., LECHOWICZ M.J. 2000. The seed bank in an old growth, temperate deciduous forest. Can. J. Bot. 78: 181-192.

LEGENDRE P., LEGENDRE L. 1998. Numerical ecology. Elsevier, $853 \mathrm{pp}$.

MATUSZKIEWICZ J.M. 2001. Zespoły leśne Polski. PWN, Warszawa, $358 \mathrm{pp}$.

MAYER P., ABS C., FISCHER A. 2004. Colonisation by vascular plants after soil disturbance in the Bavarian Forest - key factors and relevance for forest dynamics. For. Ecol. Manage. 188: 279-289.

MILBERG P. 1995. Soil seed bank after eighteen years of succession from grassland to forest. Oikos 72: 3-13.

MIREK Z., PIĘKOŚ-MIRKOWA H., ZAJĄC A., ZAJĄC M. 2002. Krytyczna lista roślin naczyniowych Polski. Instytut W. Szafera PAN, Kraków, pp. 442.

OLANO J.M., CABALLERO I., LASKURAIN N.A., LOIDI J., ESCUDERO A. 2002. Seed bank spatial pattern in a temperate secondary forest. J. Veg. Sci. 775-784.

PANUFNIK-MĘDRZYCKA D., KWIATKOWSKA-FALIŃSKA A.J. 2001. The realised and potential soil seed bank in the Potentillo albae-Quercetum community in the Białowieża primeval forest. Acta Soc. Bot. Pol. 70: 133-143.

PIROŻNIKOW E. 1983. Seed bank in the soil of stabilized ecosystem of a deciduous forest (Tilio-Carpinetum) in the Białowieża National Park. Ekol. Pol. 31: 145-172.

PLUE J., DUPOUEY J.-L., VERHEYEN K., HERMY M. 2009. Forest seed banks along an intensity gradient of ancient agriculture. Seed Sci. Res. 19: 103-114.

RALSKA-JASIEWICZOWA M., LATAŁOWA M. 1996. Poland. In: Paleoecological events during the 15000 years. Berglund B.E., Briks H.J.B., Ralska-Jasiewiczowa M., Wright H. (eds). J. Wiley \& Sons, New York, pp. 403-472.

REY P.J., GARRIDO J.L., ALCANTARA J.M., RAMIREZ J.M., AGUILERA A., GARCIA L., MANZANEDA A.J., FERNANDEZ R. 2002. Spatial variation in ant and rodent post-dispersal predation of vertebrate-dispersed seeds. Funct. Ecol. 16: 773-781.

SAS Institute Inc. 1999. SAS/STAT Users Guide, Version 8, Cary, NC: SAS Institute Inc.
SŁOMKA J. 1967. Remarks on the bioclimate of the interior of a forest (material from a Carpinetum typicum biotope) in the Białowieża National Park. Ekol. Pol. B 13: 309-323.

SOKAL R.R., ROHLF F.J. 1995. Biometry. W.H. Freeman and Company, New York, pp. 887.

THOMPSON K. 1978. The occurrence of buried viable seeds in relation to environmental gradients. J. Biogeogr. 5: 425-430.

THOMPSON K. 1986. Small-scale heterogenity in the seed bank of an acidic grassland. J. Ecol. 74: 733-738.

THOMPSON K. 1987. Seeds and seed banks. New Phytol. (Suppl.) 106: 23-34.

THOMPSON K., BAKKER J.P., BEKKER R.M. 1997. The soil seed banks of North West Europe: methodology, density and longevity. Cambridge University Press, pp. 276.

THOMPSON K., BAKKER J.P., BEKKER R.M., HODGSON J.G. 1998. Ecological correlates of seed persistence in soil in the north-west European flora. J. Ecol. 86: 163-169.

THOMPSON K., BAND S.R., HODGSON J.G. 1993. Seed size and shape predict persistence in soil. Funct. Ecol. 7: 236-241.

THOMPSON K., GREEN A., JEWELS A.M. 1994. Seeds in soi and worm casts from a neutral grassland. Funct. Ecol. 8: 29-35.

THOMPSON K., GRIME J.P. 1979. Seasonal variation in the seed banks of herbaceous species in ten contrasting habitats. J. Ecol. 67: 893-921.

VAN DER REEST P.J., ROGAAR H. 1988. The effect of earthworm activity on the vertical distribution of plant seeds in newly reclaimed polder soil in The Netherlands. Pedobiologia 31: 211-218.

VANDER WALL S.B. 1993. Seed water content and the vulnerability of buried seeds to foraging rodents. Am. Midl. Nat. 129: 272-281.

VANDER WALL S.B. 1998. Foraging success of granivorous rodents: Effects of variation in seed and soil water on olfaction. Ecology 79: 233-241.

WARR S.J., THOMPSON K., KENT M. 1993. Seed banks as a neglected area of biogeographic research: a review of literature and sampling techniques. Prog. Phys. Geogr. 17: 329-347.

WARR S.J., KENT M., THOMPSON K. 1994. Seed bank composition and variability in five woodlands in south-west England. J. Biogeogr. 21: 151-168. 